\title{
Review of Power Device for Solar-Powered Aircraft Applications
}

\author{
Bashir Danjuma Safyanu ${ }^{1, *}$, Mohd Noor Abdullah², Zamri Omar
}

\author{
Safyanu BD (D) https://orcid.org/0000-0003-1769-1090 \\ Abdullah MN iD https://orcid.org/0000-0003-1611-5892 \\ Omar Z (iD https://orcid.org/0000-0002-9572-6597
}

\author{
How to cite
}

Safyanu BD; Abdullah MN; Omar Z (2019) Review of Power Device for Solar-Powered Aircraft Applications. J Aerosp Technol Manag, 11: e4119. https://doi.org/10.5028/jatm.v11.1077

\begin{abstract}
This paper reviews various power device components of solar-powered aircraft such as photovoltaic (PV) cells, maximum power point tracker (MPPT) and rechargeable batteries. The various power device components were highlighted, and the ones applicable to aircraft were analyzed, based on criteria as efficiency for photovoltaic cells; energy densities about rechargeable batteries; and maximum power point tracker on quick response to achieve maximum power point on I-V curve. Emerging technologies like photovoltaic cells, thin film cell, organic photovoltaic cell, multi-junction cell and silicon quantum dot cell, with the future potential of high efficiencies that can be used in solar-powered aircraft, were all examined. Regarding battery technology, Lithium-air battery (Li-air) was reported as having great opportunities for high energy densities capable of improving the efficiency of the solar-powered aircraft, for the greater prospect of the aviation industry. The design of efficient power device for solar-powered aircraft application is proposed. Gallium Arsenide (GaAs) solar cells were used because of its high energy conversion efficiency of 30 to 40\%. A smart and intelligent MPPT Artificial Neural Network (ANN) is chosen because of its efficiency in partial shading and fast response and speed. The Li-air rechargeable battery is proposed because of its theoretical energy density of $11680 \mathrm{Wh} / \mathrm{Kg}$.
\end{abstract}

KEYWORDS: Solar powered aircraft, Rechargeable battery, Photovoltaic cell, Maximum power point tracker.

\section{INTRODUCTION}

Solar-powered aircraft is a remarkable concept, cutting-edge technology, and the aircraft for the future (Cleave 2008). The unlimited availability of solar radiation makes this masterpiece green technology look very promising regarding affordability, safety, sustainability and clean means of transportation (Bicer and Dincer 2017). To build the aircraft that can demonstrate enormous capability for continuous flight (Colozza 2004; Zhang et al. 2017), the idea of solar-powered aircraft design equipped with power device that includes photovoltaic (PV) cells, rechargeable batteries and maximum power point tracker (MPPT) (Reddy and Aneesh 2017; Frulla and Cestino 2008) was conceived. The PV cells are installed on the wing - the solar energy converts into electrical energy that is used to power the propulsion system and the avionics. The rechargeable battery is situated on the fuselage or any other appropriate part of the aircraft. It is used to store energy at day-time and supply power to the systems at night-time (Gao et al. 2015).

The changeable phenomena of solar energy and mode of application of solar-powered aircraft makes it imperative to analyze the power components and to come out with robust energy management and operation to accomplish a nonstop flight of $48 \mathrm{~h}$ (Ramírez-Díaz et al. 2015; Klöckner et al. 2012). For aircraft powered by solar to attain a continuous flight, Energy Management

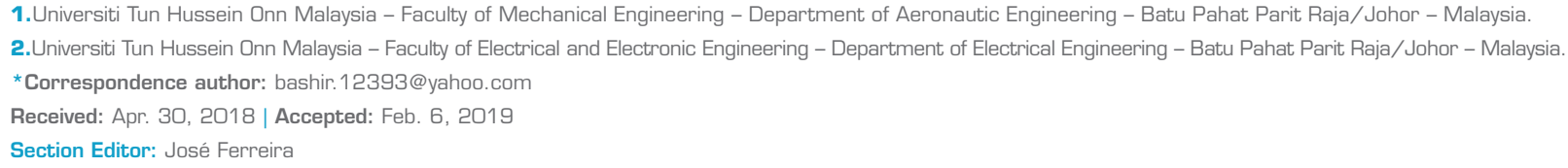


System (EMS) is required (Shiau et al. 2009). For a photovoltaic cell to produce optimal energy, MPPT device is essential. The MPPT tracks and monitors the current and voltage of the photovoltaic cells and rechargeable batteries (Noth et al. 2004). By varying the gain, it allows for the optimal energy to be extracted from the photovoltaic cells (Tsang and Chan 2013). In the Aircraft powered by solar, the MPPT is integrated into the EMS.

This paper aims to analyze the power devices of solar-powered aircraft, with the goal of discussing the advances in technologies and the developmental trend of power devices in recent years, and designing more efficient solar-powered aircraft for the growth of the aviation industry. In this paper, the different types of photovoltaic cells, rechargeable batteries, and maximum power point tracker (MPPT) technologies related to solar-powered aircraft, and its advantages compared to conventional aircraft and its future applications are discussed.

\section{NOTABLE AIRCRAFT POWERED BY SOLAR ENERGY}

The first ever aircraft powered by solar energy was sunrise I, built in 1974. It was solar powered by monocrystalline and installed with 4096PV cells that produced $450 \mathrm{~W}$ of power and 11\% efficiency (Boucher 1985). In 1980 the first ever human-crewed aircraft powered by monocrystalline was built by Dr. Paul MacCready, named as a Gossamer penguin. He also created Solar Challenger installed with 16,000 solar cells mounted on its wings, that generated $2500 \mathrm{~W}$, without energy storage devices (MacCready et al. 1983). In 2005 Alan Cocconi produced SoLong with SunPower A300 monocrystalline solar cell, which provided a power of $225 \mathrm{~W}$ and storage device of Lithium-ion battery of $1200 \mathrm{Wh}$ (Ross 2008). Zephyr 7, in 2010, had installed with amorphous silicon with 19\% efficiency and a lithium Sulphur battery of 500-600 Wh/kg energy density (Mecrow et al. 2010). The Solar Impulse I, in 2009 , is installed with monocrystalline solar cells of 11,628 with $18 \%$ efficiency and 84 W. Lithium polymer battery with an energy density of $240 \mathrm{Wh} / \mathrm{kg}$ was used (Leutenegger et al. 2011). And recently the Solar Impulse II flew around the world from 2014 to 2016 . The aircraft was installed with 17,248 monocrystalline solar cells and produced a power of $66 \mathrm{KW}$ and battery made of Lithium-ion (Hutchinson 2016).

\section{SOLAR-POWERED AIRCRAFT POWER DEVICE COMPONENTS}

The design of an solar-powered aircraft comprises of power components which include the photovoltaic cells, maximum power point tracker (MPPT) and rechargeable battery (Cleave 2008). Usually, the photovoltaic cells are installed in the wings and tail of the aircraft to convert solar energy into electrical energy to power the propulsion system and avionics. The battery is fitted in the fuselage and inside the wing or any other part of the aircraft. It charges during the day, when the solar energy is abundant, and discharges to power the aircraft and avionics at night. The nature of the solar radiation inclination, climatic condition, time of the day and year and cell orientation, make it impossible for solar energy to be available at optimum level at all time (Rajendran and Smith 2015; Pande and Verstraete 2018). MPPT is used to get maximum solar energy from the photovoltaic cells. The MPPT track and ensure current and voltage works for a maximum power irrespective of changes in atmospheric conditions or load and optimizes the working of PV cells (Fazelpour et al. 2013). Figure 1 shows the power device of solar-powered aircraft.

\section{PHOTOVOLTAIC CELL}

PV cell translates solar energy into electrical energy. A P-N junction displays a voltage and current intricate link in the solar cell (Arjyadhara et al. 2013). When the solar light falls on the cell, voltage and current are the products which show the intricate connection between insolation and output power (Dimova-Malinovska 2010). Under a bright light condition, the solar cells capture slows moving low energy electrons. Energy is lost due to saturation of the solar cell (Bialasiewicz 2008). When the insolation is low, the power generated will be high, while higher insolation will reduce generated power due to the saturation of cells, and the number of free electrons or their mobility decreases significantly (Esram and Chapman 2007). 


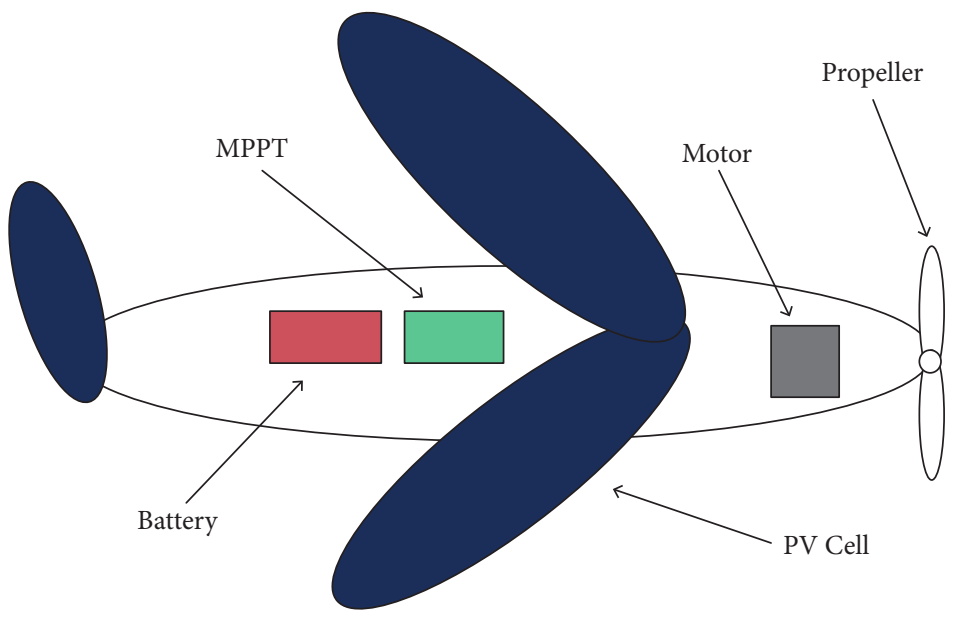

Figure 1. The power device of solar-powered aircraft (Gao et al. 2015).

Figure 2 shows the I-V characteristic of the intricate link between voltage and current relationship. The open voltage is the voltage across the terminal in an open circuit and the short circuit current is the current passing through the wire is short-circuited while the voltage is zero.

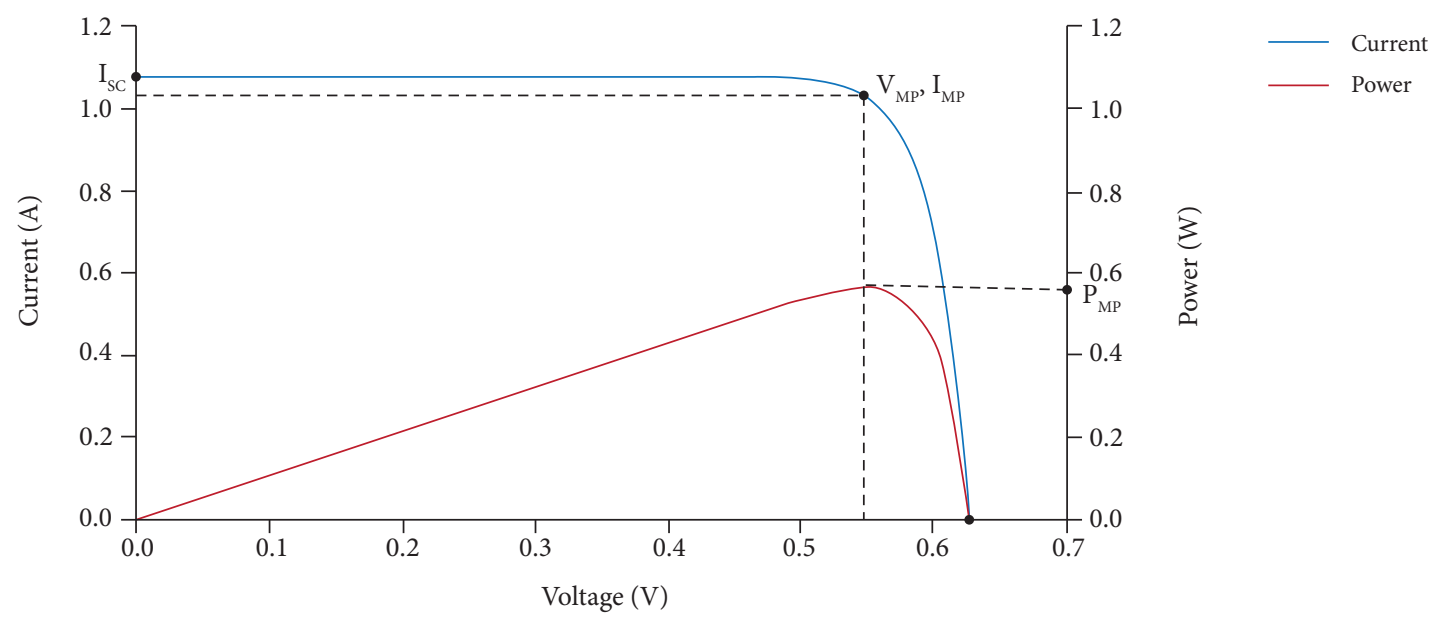

Figure 2. I-V Curve of a typical solar cell (Khurana et al. 2014).

\section{CLASSIFICATION OF PHOTOVOLTAIC CELLS}

Photovoltaic cells are classified based on the materials used for the solar cell production and groups as follows: crystalline silicon, thin film, organic/polymer, hybrid PV and dye-sensitized photovoltaic cell (Tyagi et al. 2013). Figure 3 shows the classification of PV cell based on PV material. The mode of PV cell energy operation is hypothetically similar, but varies in material and manufacture (Emery 2004).

The complementary effort of both researchers and manufacturers to reducing the production cost and improving the energy conversion efficiency of solar cells have greatly contributed to the affordability of solar energy (Abbe and Smith 2016). Although different solar cells types exist in the market, very few are applied to aircraft powered by solar energy due to the following reasons: capability of energy transformation efficiency, cost-consideration, environmental compliance, weight of the substrate, flexibility and consistency (Fazelpour et al. 2013). Silicon cell is the predominant photovoltaic cell used in solar-powered aircraft (Ghosh et al. 2017). 


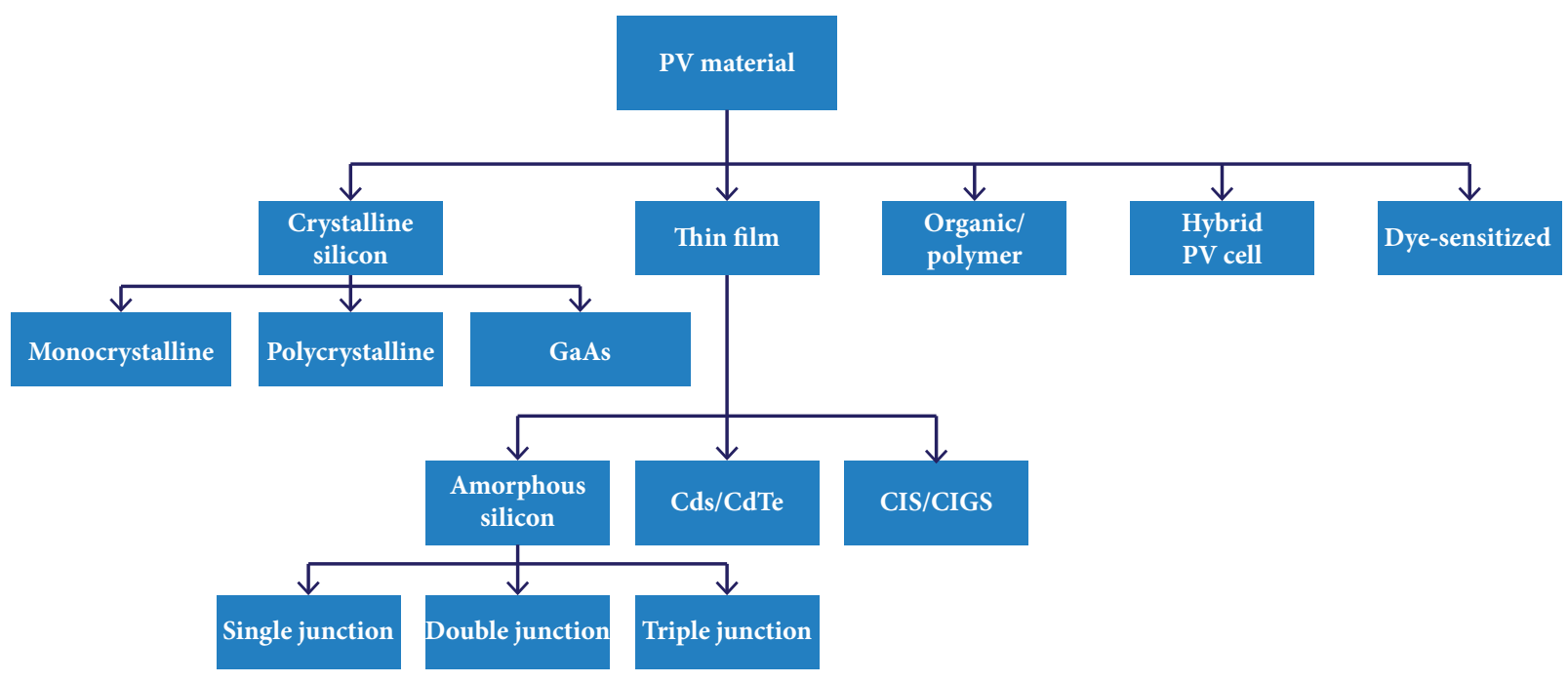

Figure 3. Classification of photovoltaic cell based on PV material (Tyagi et al. 2013).

\section{Crystalline Material}

Crystalline material PV cell comprises mono-crystalline, poly-crystalline and gallium arsenide (GaAs) cells. They are described as follows:

- Mono-crystalline silicon cell is a type of cell with a unique structure and uniform shape from a single-crystal (Arjyadhara et al. 2013). A pure silicon ingot produced from molted raw silicon. The silicon ingot is cut into thin wafers, polished, doped, coated, interconnected and assembled into modules and arrays. Monocrystalline silicon cells are mostly applicable to photovoltaic panel construction. The unique structure of the silicon wafer allows mobility of electrons from the material, which results in high energy conversion efficiency (Latukhina et al. 2015). Mono-crystalline cell has conversion efficiency between 15\% and 20\%. For PV cell to be applicable, the silicon has to be "doped" with other elements to make the required $\mathrm{N}$-type and P-type conductive layer (Femia et al. 2006). Mono-crystalline cells are used for outdoor and solar-powered aircraft applications mainly due to their wafer thickness and conversion efficiency. However, monocrystalline cell application in solar-powered aircraft is faced with the problem of encapsulation of the solar cell on the cambered wing of the aircraft. Two methods are adapted to expertly bend the solar cell to follow the shape of the airfoil. In the first method, adhesive coating is used to lay the solar cell on the airfoil (Gao et al. 2015; Danjuma et al. 2018). The second method makes use of the flat-paneled airfoil specially intended for aircraft powered by solar energy (Chen and Bernal 2008).

- Polycrystalline silicon consists of different smaller grains of crystals which form the molecular structure, also creating boundaries between them (Becker et al. 2011). The energy conversion efficiency of polycrystalline cells is less compared to monocrystalline silicon cells due to limitations of electrons flow because the negative electrons are charged to form a union with the positive holes, resulting in reduced power output of the cell (Fraas 2014). The polycrystalline energy conversion efficiency is between 10 and $14 \%$. These types of photovoltaic cells are cheaper to manufacture compared to monocrystalline silicon because of the reduced production cost (Khan and Arsalan 2016).

- Gallium Arsenide (GaAs) is a semiconductor material formed as a result of a combination of Gallium (Ga) and Arsenic (As), generating related or silicon-like structure (Becker et al. 2011). GaAs with a band gap of $1.43 \mathrm{eV}$ has high efficiency and less thickness, when compares to the silicon-based solar cell (Kazmerski 2006; Iles 2001). Alloying with Aluminium, Indium, Phosphorus, and Antimony can increase the efficiency of GaAs. When GaAs is alloyed, a multi-junction device is formed, leading to an increase in the band gap value (Satyen 1998). Due to the high resistance of GaAs, it is applied in a concentrator PV module and space mission (Hillhouse and Beard 2009). The high energy conversion efficiency of 30\% to $40 \%$ and the flexibility of the solar cell make it the best solar cell for solar-powered aircraft application. The solar cell 
is flexible, so it can easily bend to the airfoil shape of the aircraft. The solar cell is more expensive than a monocrystalline solar cell, reason why it is not widely used.

\section{The Thin Film PV Cell}

This type of PV cell is manufactured directly by using a thin film semiconductor layer of PV material printed or sprayed on a glass, metal or plastic foil substrate (Aberle 2009). The PV cell thickness is smaller when compared to cut crystalline cell. The manufacturing process of this PV cell is faster and affordable because the PV is sprayed or printed on a glass and metal substrate. Thin film cells have higher light absorption capability compared to crystalline cells (Bossert et al. 2000), and they have low cell conversion efficiency due to the absence of crystalline structure, requiring more substantial sized cells. Cadmium Telluride, Amorphous Silicon, and Copper Indium di-Selenide or CIS are all types of thin PV cells.

- Amorphous Silicon (a-Si) cell is of a thin film structure with silicon extract but non-crystalline. This type of cell applies to small electronics products with low voltage rating. Amorphous silicon light absorption is 40 times higher than crystalline silicon (Meier et al. 2004). It gives amorphous silicon materials benefit because of the much thinner layer that is essential to produce a thin film PV cell, thereby making it very cheap in production and affordable. The advantage of amorphous silicon cells is that it can be stamped on various types of cheap materials, both flexible and rigid substrates, from polymers, thin metals, plastics, to tinted glass. The PV cell efficiency is 7\% to 9\%, and 5\% when exposed to sunlight for a few months after installation (Meier et al. 1994). The low energy conversion efficiency affects its application in solar-powered aircraft.

- Cadmium Telluride (CdTe) and Cadmium Sulphide (CdS) is manufactured through thin CdS layer which evaporates on a conductive glass substrate, then a thick CdTe layer is evaporated, and a metal contact layer is deposited to complete the process (Hegedus et al. 2007). The cell is heated with $\mathrm{CdCl}_{2}$ flux that initiates crystallization of the semiconductor at a temperature of around $450^{\circ} \mathrm{C}$, and this permits copper $\mathrm{CdS}$ to be doped in a similar process (Hegedus and McCandless 2005). CdS/CdTe has been established to be stable for a very long time (Böer 2011). It can also produce an efficiency of $15 \%$ and $1.45 \mathrm{eV}$ of band-gap due to high direct absorption coefficient (Britt and Ferekides 1993).

- Copper Indium Gallium Selenide/Copper Indium Selenide is the latest innovation that has a potential to contend with silicon solar cell. CIGS/CIS efficiency can reach up to $13 \%$ for a module and $20 \%$ for the cell (Repins et al. 2008). It can attain a high value of $1.68 \mathrm{Ev}$ of bandgap with a small amount of change with Sulphur (S). The progress of CIGS solar cell was monitored under lifetime indoor (under STC) and outdoor for four months through an experiment carried out by Radue et al. (2009). Any trace of defects found in the module can cause a low current in the cell. An investigation of the progress of CIS and the similar thin-film cell was conducted by (Meyer and Dyk 2003). After the study, the results, when compared to another thin-film cell CIS, only reduced by $10 \%$ when exposed to $130 \mathrm{kWh} / \mathrm{m}^{2}$ outdoor. The absorption coefficient of $\mathrm{CuInSe}_{2}$ is above $105 \mathrm{~cm}^{-1}$.

\section{Organic and Polymer Cells}

It is a relatively a new technology that looks promising and attracted the interest of researchers working on it because of the following reasons: physical flexibility, disposable, and cost-efficient material (Goetzberger et al. 2003). An investigation into the efficiency of the polymer cell used in PV-powered boats was carried out by McCann et al. (2001). The study was also carried out on properties of materials on the polymers, which include thickness, strength, density, UV stability, and temperature, among others. The results show that polymers have properties to replace silicon PV modules due to cost and weight factors in the nearest future. Organic materials have a significant disadvantage as PV cell because the highest open circuit voltage ever recorded was $4 \mathrm{~V}$, which is very insignificant. However, the output voltage of organic materials increased due to use of broad absorption band material (Peumans et al. 2003).

\section{Hybrid Solar Cell}

A hybrid solar cell is formed by the fusion of crystalline silicon with non-crystalline silicon (Itoh et al. 2001). The integration of amorphous silicon with crystalline silicon produces a high-performance ratio of the solar cell (Itoh et al. 2001). The highest efficiency 
generated by hybrid solar cell was $21 \%$ by Sanyo solar cell (Tanaka et al. 1992). It is a combination of Heterojunction and Intrinsic thin film layers' solar cell (HIT). The base of this solar cell is an n-type CZ silicon wafer that functions as a light absorber. This type of solar cell can be used for solar-powered aircraft because of its energy conversion efficiency.

\section{Dye-Sensitized Solar Cell}

A type of solar cell that a semiconductor film produces by the photo-sensitized anode and an electrolyte. The surface of the semiconductor is absorbed with a sensitizer that contains an electrolyte with a redox mediator and counter electrode capable of regenerating the redox mediator like platine (Nazeeruddin et al. 2011). The dye-sensitized solar cell is a useful technology compared to the existing ones (Michael 2003).

\section{THE EMERGING TECHNOLOGY TRENDS}

In the area of solar-powered aircraft, several technologies are emerging, most of which are under research, while others are in the prototype stage. These technologies can improve the efficiency of the solar-powered aircraft.

\section{PHOTOVOLTAIC}

Thin-film technologies of solar cells have improved with time. Amorphous silicon cells are mostly produced from waste recycled computer chips. Various methods for manufacturing of thin-film cells include the followings: physical vapor deposition, plasma-enhanced chemical vapor deposition, and sputtering. As a result of improved performance when the temperature is high as opposed to crystalline silicon cells, thin-film cells application has dramatically increased (Han et al. 2017).

Multi-junction cells are mostly produced from Gallium Indium Phosphide (GaInP), Gallium Arsenide (GaAs), and Germanium (Ge) p-n junctions. They have the potential to convert much broader light frequencies. When compared to another solar cell, it hardly loses efficiency at high temperature and its efficiency can be greater than $40 \%$. The recent technology can make it possible to get efficiency as high as 50\% in the next ten years (Essig et al. 2015; (Danjuma et al. 2018). The multi-junction solar cell, due to its optimal conversion efficiency and flexibility, has an advantage in a future application in solar-powered aircraft (Pande and Verstraete 2018).

Quantum dots are innovations capable of boosting the efficiency of solar cells by increasing the value of the bandgap of solar cells to absorb more light in the solar spectrum so that it can produce charges efficiently from a single photon (Nozik 2002). Quantum dots solar cell have the capacity, theoretically, to translate $66 \%$ and above of the solar energy into electrical energy, almost expanding the efficiency of solar cells (Nozik 2002). Silicon quantum dot (SiQD) in dielectrics is the suitable material used for manufacturing of solar cell. The limitation of the decrease in the dimensions of the Silicon to less than $5 \mu \mathrm{m}$ efficiently increase the bandgap, thereby increasing the cell efficiency (Nozik 2002).

Nanomaterials such as nano-wires and nano-particles have an advantage in applications compared to photovoltaic materials. The nanometer-size objects have a substantial interfacial area because of the significant surface area per unit volume. The nano size creates a quantum confinement effect, which provides an opportunity to design nano-materials with various bandgaps. The polychoral carbon nanotubes is a solar cell just like quantum dots; this can improve the bandgap and subsequently increase the efficiency to meet optimal requirements.

The technology can also be used to create an airframe of the aircraft. The thin film carbon nano-tubes and nano-fibers are typical examples of solar cell technologies. These have been indiscriminately adapted to and magnetically united, to be tenfold lighter and 500 fold stronger than steel (Gong et al. 2014). They exhibit electrical conductivity similar to copper or silicon and disperse heat identical to brass and steel. This characteristic adequately improved the performance of the solar cell and made it affordable (Dimova-Malinovska 2010).

In the nearest future, the aviation industry looks very promising with technological advancement and break-through research findings in aircraft powered by solar energy. 


\section{RECHARGEABLE BATTERIES}

The rechargeable battery in aircraft powered by solar energy is vital to sustain continuous flight and high altitude and long endurance (HALE) (Barbosa et al. 2014). The rechargeable battery stores extra power during daytime and uses the power in the night.

Energy density is used to determine the efficiency of a rechargeable battery. The energy density is defined as the quantity of energy stored in a given system per unit mass. The energy density is given as (Eq. 1)

$$
\bar{m}_{b}=\frac{E}{m_{b}}
$$

where $E$ is stored energy and $m_{b}$ is the mass of the rechargeable battery (Gao et al. 2015).

Due to the significance of the energy density to the solar-powered aircraft, a consistent effort is being put up to improve the energy density (Braun et al. 2012). Figure 4 shows the power and energy density of various rechargeable batteries.

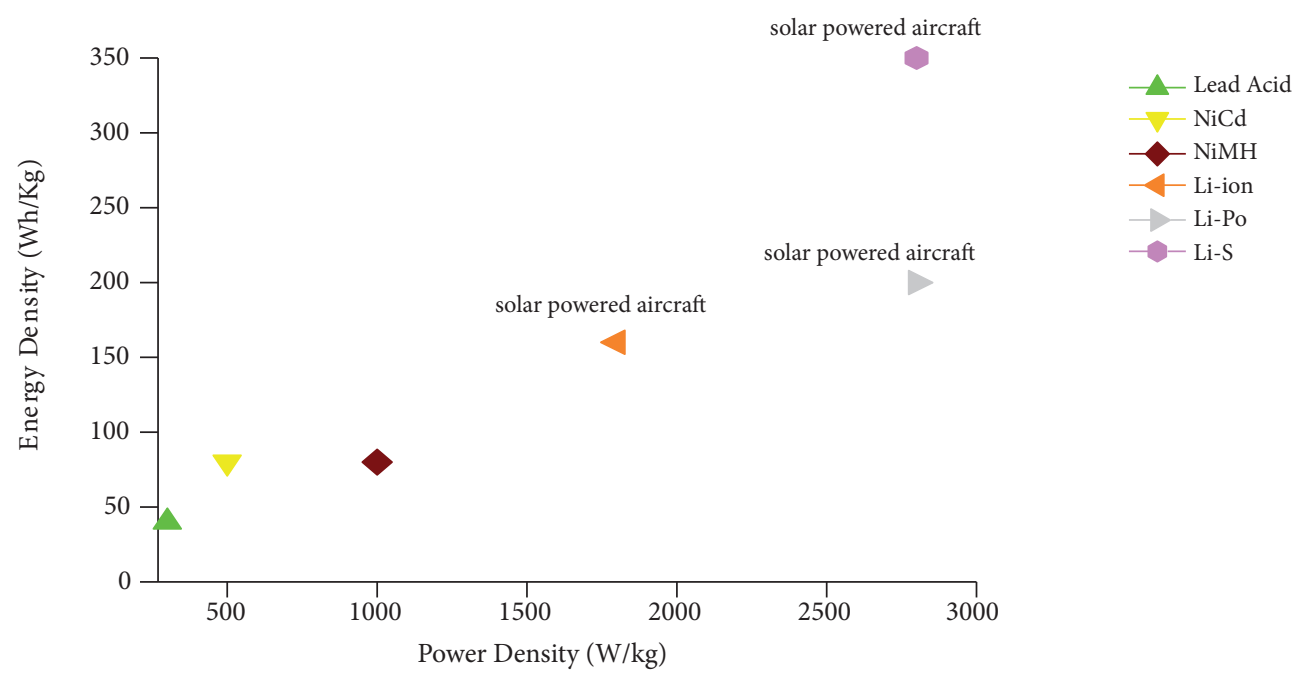

Figure 4. The power and energy density of various rechargeable batteries (Padbury and Zhang 2011; Braun et al. 2012).

A limitation of aircraft powered by solar energy is the low energy densities of the power propulsion. For this reason, highenergy density storage device is inevitable (Sliwinski et al. 2017). There are different energy storage devices, but their choice is determined by their area of application (Wagner 2007).

\section{Classification of the Rechargeable Battery}

Rechargeable batteries are classified from the early invention of Nickel-Cadmium, Nickel-Metal-Hydride to up to date invention of Lithium-ion, Lithium Polymer, and Lithium Sulfur, based on their energy densities.

- Nickel-Cadmium Battery has both Nickel and Cadmium electrodes in a Potassium Hydroxide solution. Early type battery uses an alkaline electrolyte (Rydh and Karlström 2002). The batteries are powerful and had a better energy density of 40 to $60 \mathrm{wh} / \mathrm{kg}$ than lead-acid batteries.

- Nickel-Metal-Hydride Battery is a modification of Ni-Cd by replacing the cadmium electrode with hydrogen-absorbing alloy. NiMH batteries do have longer lifespans than Ni-Cd batteries (Hasegawa et al. 1994). Cadmium is poisonous compared to NiMH batteries, which are more environmentally friendly.

- Lithium Batteries. Lithium metal has a considerable advantage to be used as rechargeable batteries because of strong electrochemical potential, lowest density and the energy-to-weight ratio (Tudron et al. 2004). In 1912, experiments with 
lithium were carried out, and the first set of lithium-based batteries was introduced in 1970 . This rechargeable battery was the most stable version and first sold out in 1991 (Goodenough and Park 2013). Lithium batteries electrolyte are made of the solid polymer composite, not a conventional liquid solvent, the electrodes and separators are both laminated to each other (Scrosati and Garche 2010). Due to the solid nature of the electrolyte it is possible for the battery to be encased in a flexible wrapping, rather than a rigid metal casing. Also, this makes it possible for the batteries to be shaped precisely to fit a particular device (Goodenough 2012). Because of their flexibility and compact design, these batteries have an edge to be used for solar-powered aircraft, mobile phones and PDAs.

- Lithium-Sulphur (Li-S) battery is an energy storage device with the specific capacity of $600 \mathrm{mAh} / \mathrm{g}$ and specific energy density of $2600 \mathrm{wh} / \mathrm{kg}$, theoretically when lithium to the sulphur reaction is fully completed. The highest theoretical energy density is attained by lithium battery (Jeon et al. 2002). Interest is geared towards lithium-sulphur battery because of its enormous energy density and affordability of sulphur compared to lithium-ion and lithium-polymer batteries, which have low energy densities. Sulphur to lithium sulphide (Li-S) undergoes complete reaction; this will produce sulphur with a specific capacity of $1675 \mathrm{Ah} \mathrm{Kg}^{1}$ and an energy density of $2600 \mathrm{Wh} / \mathrm{Kg}$, which is 3 to 5 times higher than that of Lithium-ion batteries (Zhang 2013). The lithium-sulphur battery is used in Zephyr 7.

\section{ADVANCEMENT IN BATTERY TECHNOLOGY}

With the current growth and development of electronic devices, electric vehicle and solar-powered aircraft, there is a high demand for the high energy density of storage systems (Wagner et al. 2010). To date, lithium-ion, lithium-polymer, and lithiumsulphur are the rechargeable batteries used for solar-powered aircraft. They have a limited energy density of $250 \mathrm{to} 700 \mathrm{Wh} / \mathrm{kg}$, which is insufficient for emerging technology applications (Cairns and Albertus 2010).

Li-air batteries have potential to power various applications in the future, most especially solar-powered aircraft and electric vehicle, mainly because of their great theoretical energy density of $11680 \mathrm{Wh} / \mathrm{kg}$ at average, than those of the existing batteries. The Li-air battery high energy density is a remarkable technological breakthrough when compared with the energy density of gasoline as $13000 \mathrm{Wh} / \mathrm{kg}$ (Tan et al. 2017). It shows that Li-air battery is the key to solar-powered human-crewed aircraft to compete with the conventional aircraft in the nearest future.

Despite the emergence of numerous rechargeable energy storage applications, metal-air batteries are the most vital to improving the energy density capacity, especially lithium-air, aluminium-air, and zinc-air batteries (Lee et al. 2011).

\section{MAXIMUM POWER POINT TRACKER (MPPT)}

Maximum power point tracker traps the maximum power point (MPP) on the I-V curve to get maximum power from the photovoltaic cell (Ahmed and Salam 2014). PV arrays have non-linear I-V characteristics and output power depends on the condition of the solar irradiance. The maximum power point (MPP) on the I-V curve is the point where power is maximum (Bialasiewicz 2008). MPPT is used to get available maximum power from the PV cell, as the MPP position keeps on fluctuating with changing solar irradiance (Wang et al. 2011). The MPPT track the PV operating voltage and current consistent to MPP and locks its, geting the maximum power on PV array to the systems (Kobayashi et al. 2003).

The MPPT is formed with a component of power conversion efficiency. Various algorithms for MPPT are available, each with different features and principle of operation (Sahnoun et al. 2013)there exist many maximum power point tracking (MPPT. The success of solar-powered aircraft energy is a fundamental issue (Noth 2008) that relies on the MPPT tracking precision and energy tracking factor. For optimum performance of solar-powered aircraft to be attained, the advanced power management system is installed in them, so that photovoltaic cells can be on the maximum power point level, irrespective of whether the highperformance are producing power for propulsion or energy storage mode (Davey 2009).

MPPT methods are categorized into indirect and direct methods (Esram and Chapman 2007). The indirect methods are open circuit and short circuit methods, where PV characteristic is required or based on mathematical relationship. There is no 
need for meteorology conditions, that is, irradiance and temperature, to track the maximum power point (Park and Yu 2004). The direct methods are $\mathrm{P} \& \mathrm{O}$, incremental and conductance method and fuzzy logic. These methods follow the MPP under meteorological conditions (Salas et al. 2006). MPPTs are also categorized as intelligent and conventional methods. As shown in Table 1, intelligent techniques include Fuzzy logic (FL) and Artificial neural networks (ANN). These MPPT methods are very efficient, with fast response, and are more complicated compared to the conventional techniques that are simpler, cheaper and less efficient, such as $\mathrm{P} \& \mathrm{O}$ and incremental conductance methods (Ram et al. 2017; Bouselham et al. 2017). Table 1 depicts the major characteristic of MPPT about solar-powered aircraft. The intelligent MPPTs are more suitable in solar-powered application than the conventional type.

Table 1. Major characteristics of MPPT methods (Bhatnagar and Nema 2013).

\begin{tabular}{|c|c|c|c|c|c|c|c|c|}
\hline MPPT method & Complexity & $\begin{array}{c}\text { PV array } \\
\text { dependent }\end{array}$ & $\begin{array}{c}\text { Direct or } \\
\text { indirect }\end{array}$ & $\begin{array}{c}\text { Analog. } \\
\text { or digital }\end{array}$ & Efficiency & $\begin{array}{c}\text { Response/ } \\
\text { speed }\end{array}$ & $\begin{array}{c}\text { Tracking } \\
\text { accuracy }\end{array}$ & $\begin{array}{c}\text { Efficient for } \\
\text { partial shading }\end{array}$ \\
\hline $\begin{array}{c}\text { P\&O } \\
\text { IncCond }\end{array}$ & Simple & No & Direct & Both & Low & Varies & Medium & No \\
\hline $\begin{array}{c}\text { Open-circuit } \\
\text { voltage method }\end{array}$ & Simple & No & Direct & Digital & Medium & Varies & High & Yes \\
\hline $\begin{array}{c}\text { Short-circuit } \\
\text { current method }\end{array}$ & Simple & Yes & Indirect & Both & Low & Medium & Medium \\
\hline $\begin{array}{c}\text { Fuzzy logic } \\
\text { Indirect }\end{array}$ & Complex & Yes & Both & Medium & Medium & Medium & Yes \\
\hline Neural networks & Complex & Yes & Indirect & Digital & High & Fast & Very high & Hes \\
\hline
\end{tabular}

\section{PROSPECTS TO THE AVIATION INDUSTRY}

The latest technological breakthrough and contribution of researchers in solar-powered aircraft make the sector very promising. The challenges faced by aircraft powered by solar energy for high altitude long endurance (HALE) flight, day and night throughout the year, in all regions of the world is becoming a dream come through in the nearest future. Researchers are working day and night, and grants are provided by both public and private investors for research and development (R\&D) to provide sustainable, safe and affordable means of transportation using solar energy entirely as a source of energy.

\section{LATEST TECHNOLOGY TRENDS OF SOLAR-POWERED AIRCRAFT}

Latest technology trends in solar-powered aircraft power devices showcase the future image of the aviation industry in a few years to come. Solar-powered aircraft is a system whereby solar energy is used to power the propulsion component and the avionics, sensors and electrical systems of an aircraft. Solar-powered aircrafts can be optimized by lowering the power loading to achieve higher propulsion and aerodynamic efficiencies. The high efficiency of an aircraft is the total sum of the respective component efficiencies of propulsion, aerodynamic and structural components (Cleave 2008).

Nanotechnology provides advanced composite materials for airframe structural developments in aerospace technology applications. This technology is used to produce lighter and stronger materials to withstand aerodynamic and inertial loading with an excellent characteristic of electrical and thermal conductivity.

Smart technologies allow the synchronization of sensors and avionics systems to be portable, lighter, reliable, and to perform better. Also, enable the synchronization to apply to the following components of power device: sensing, control and actuation.

\section{APPLICATIONS OF SOLAR-POWERED AIRCRAFT}

Solar-powered aircrafts have the capability for a continuous flight because of the abundant and unlimited quantity of solar energy (Cestino 2006). The legendary durability of aircrafts powered by solar energy is inestimable, with the potential to be used 
as satellites for very long periods unless it got damaged (Fujita et al. 2012) Global Hawk UAV is the first to practically show the advantage of high altitude long endurance flights when it flies over $18.2 \mathrm{~m}$ for several days (Stacy et al. 2002). Also the Zephyr 7 in 2010 flew continuously for 14 days (Morton et al. 2015). Recently, in 2016, solar impulse 2 Bertrand Piccard and Andre Borschberg flew the first long human-crewed solar-powered aircraft approximately 40,000 km in 17 months, around the world flight, completed on July 24, 2016. Solar powered aircraft can fly to attain altitudes higher than $30 \mathrm{~km}$ because of solar energy is abundantly available for these aircraft (Hutchinson 2016).

The capability of continuous flight of solar-powered aircraft (UAV) near space makes it possible for application in intelligent surveillance and renaissance (ISR) and relay communication (Najafi 2011), hazard warning, rescue and assessment, agricultural surveillance and decision support systems, and near future planetary atmospheric exploration by NASA (GómezCandón et al. 2011)which consists of geo-referenced coloured tarps acting as terrestrial targets (TT. Also, the application of human-crewed solar-powered aircraft demonstrated by Solar Impulse 2 looks very bright for the aviation industry.

However, with the current technology development in various power devices of solar powered-aircraft, the design of efficient power device in solar-powered aircraft application is proposed as shown in Fig. 5. The PV cell (GaAs) is used due to its high energy conversion efficiency of $30 \%$ to $40 \%$. The MPPT intelligent and smart algorithm (Artificial Neural Network) is chosen because it is very efficient in partial shading and the response/speed is fast. The rechargeable battery (Li-Air) is selected for its possible theoretical high energy density of $11680 \mathrm{Wh} / \mathrm{kg}$, which can sustain long endurance flights in the nearest future.

Different rechargeable batteries and their energy densities applied to aircraft powered by solar energy and the duration of the flight is shown in Fig. 6. Table 2 depicts the application and installation of various PV cells and batteries in solar-powered aircraft. Also, Fig. 7 shows the application of MPPT in solar-powered aircraft.

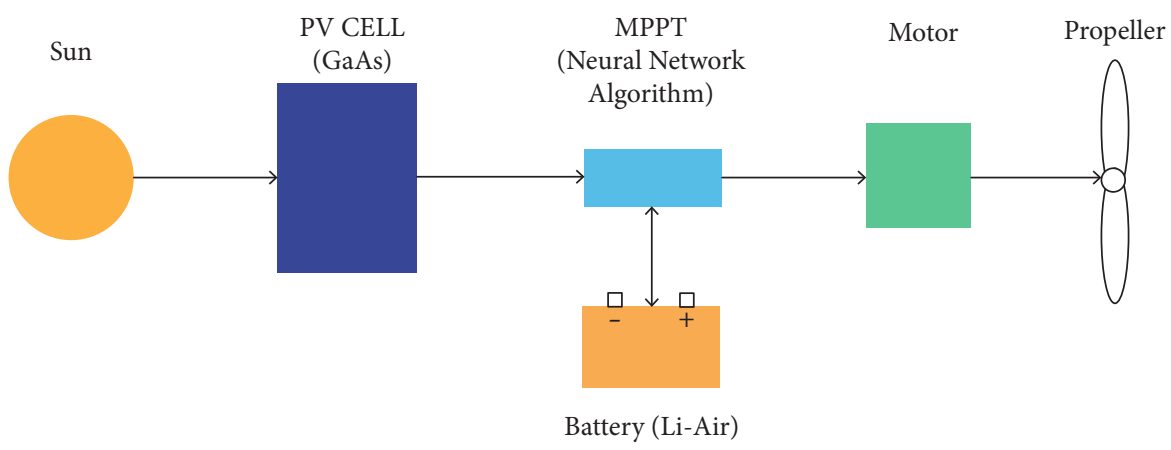

Figure 5. Proposed efficient power device in solar-powered applications.

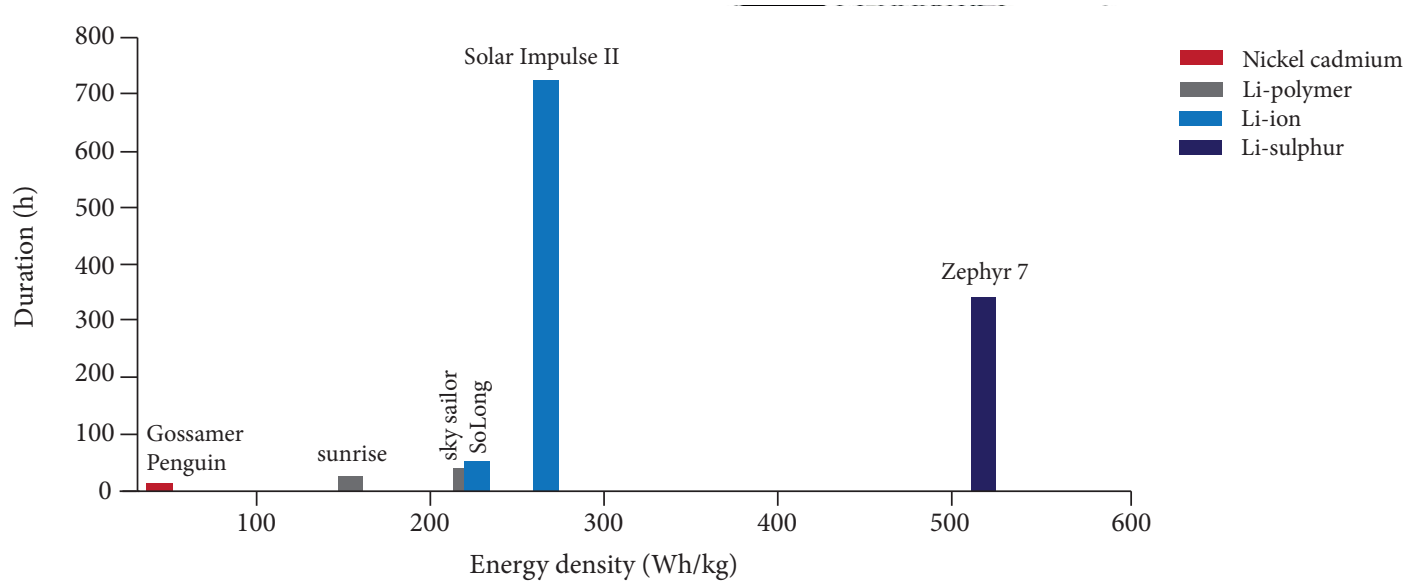

Figure 6. Solar-powered aircraft energy density and flight duration. 
Table 2. Application and installation of different PV cells and batteries on solar-powered aircrafts.

\begin{tabular}{|c|c|c|c|c|c|c|}
\hline \multirow[b]{2}{*}{ Name } & \multirow[b]{2}{*}{ Year } & \multicolumn{3}{|c|}{ Photovoltaic } & \multicolumn{2}{|c|}{ Battery } \\
\hline & & PV Cell & $\begin{array}{c}\text { Efficiency } \\
{[\%]}\end{array}$ & $\begin{array}{l}\text { Power } \\
\text { [w] }\end{array}$ & Battery & $\begin{array}{l}\text { Specific energy } \\
\text { [Wh/Kg] }\end{array}$ \\
\hline $\begin{array}{c}\text { Sunrise I } \\
\text { (Boucher 1985) }\end{array}$ & 1974 & Monocrystalline & 11 & 400 & Li-ion polymer & 145 \\
\hline $\begin{array}{c}\text { Sunrise II } \\
\text { (Boucher 1985) }\end{array}$ & 1975 & Monocrystalline & 16.1 & 600 & Li-ion polymer & 145 \\
\hline $\begin{array}{l}\text { Gossamer Penguin } \\
\text { (MacCready et al. 1983) }\end{array}$ & 1983 & Monocrystalline & 13.2 & 600 & Nickel Cd & 50 \\
\hline $\begin{array}{c}\text { Solar Challenger } \\
\text { (MacCready et al. 1983) }\end{array}$ & 1981 & Monocrystalline & 13 & 250 & Nickel Cd & 50 \\
\hline $\begin{array}{c}\text { Sky Sailor } \\
\text { (Noth et al. 2006) }\end{array}$ & 2004 & Monocrystalline & 18 & 84 & Li-ion polymer & 172.8 \\
\hline $\begin{array}{c}\text { So-Long } \\
\text { (Hartney 2012) }\end{array}$ & 2005 & Monocrystalline & 18 & 220 & Li-ion & 220 \\
\hline Solar Impulse I & 2009 & Monocrystalline & 18 & 240 & Li-ion polymer & 240 \\
\hline $\begin{array}{c}\text { Zephyr } 7 \\
\text { (Davey 2009) }\end{array}$ & 2010 & Amorphous Silicon & 19 & & Lithium-sulphur & $400-600$ \\
\hline Solar Impulse II & $2014 / 2016$ & Monocrystalline & 18 & 260 & Li-ion & 260 \\
\hline & & & MPPT & & Motor & \\
\hline Sun & & V CELL & $\begin{array}{ll}\square & \downarrow \\
- & +\end{array}$ & & & $\begin{array}{l}\text { peller } \\
\text { pello }\end{array}$ \\
\hline
\end{tabular}

Figure 7. MPPT controller in solar-powered aircraft applications.

\section{CONCLUSION}

The solar-powered aircraft power system component comprises photovoltaic cells, rechargeable battery and MPPT. Photovoltaic cells are classified based on materials for solar cell production and are grouped as follows: Crystalline silicon, thin-film, organic/ polymer, hybrid PV, and dye-sensitized photovoltaic cell.

The energy density is the most prominent feature to be considered in rechargeable batteries performance. The early stage of rechargeable batteries are low energy density characterizes lead-acid, nickel cadmium, nickel metal-hydride batteries; and later stage are lithium-ion, lithium polymer, and lithium-sulfur, which have an advantage because of their higher energy densities.

The MPPT is the critical component of power conversion efficiency and various algorithms for MPPT are available, each with different features and principles of operation, to ensure the success of solar-powered aircraft design. To get the optimum performance of aircraft powered by solar energy, advanced powered management system is installed. 
Emerging technologies provide opportunities shortly for solar aircraft. Thin-film solar cells performance has improved significantly with technologies over time. Multi-junction cells are solar cells with high efficiency ranges, from $40 \%$ to $50 \%$. Quantum dots are another solar cell that boosts the bandgap value to harness considerable amount of light coming into the solar spectrum and produces adequate charges from a single photon. All this improved the efficiency of the solar cell.

Regarding battery technology, Li-air batteries have potential to provide energy to different applications, most especially solar-powered aircraft and electric vehicle, primarily because of their high theoretical energy densities, $11680 \mathrm{Wh} / \mathrm{kg}$ at average, compared to existing batteries.

With the improvement in technology, an efficient powered device is proposed for solar-powered aircraft application. The capability of continuous flight, high altitude and long endurance of solar-powered aircraft (UAV) in near space makes it possible for its application in intelligent, surveillance and renaissance (ISR) and relay communication, hazard warning, rescue and assessment, agricultural surveillance and decision support systems, and near future planetary atmospheric exploration by NASA.

\section{AUTHORS' CONTRIBUTION}

Conceptualization, Safyanu BD, Abdullah MN and Omar Z; Methdology, Safyanu BD, Abdullah MN and Omar Z; Investigation, Safyanu BD and Abdullah MN; Writing - Original Draft, Safyanu BD, Abdullah MN and Omar Z; Writing - Review and Editing, Safyanu BD, Abdullahi MN and Omar Z; Funding Acquisition, Abdullah MN; Resources, Safyanu BD, Abdullah MN and Omar Z; Supervision, Safyanu BD and Abdullah MN.

\section{FUNDING}

Universiti Tun Hussein Onn Malaysia [https://doi.org/10.13039/100007837]

Grant no. U684

\section{REFERENCES}

Abbe G, Smith H (2016) Technological development trends in solar-powered aircraft systems. Renewable and Sustainable Energy Reviews 60:770-783. https://doi.org/10.1016/j.rser.2016.01.053

Ahmed J, Salam Z (2014) A Maximum Power Point Tracking ( MPPT ) for PV system using Cuckoo Search with partial shading capability. Applied Energy 119:118-130. https://doi.org/10.1016/j.apenergy.2013.12.062

Arjyadhara P, Ali SM, Chitralekha J (2013) Analysis of solar PV cell performance with changing irradiance and temperature. International Journal of Engineering and Computer Science 2(1):214-220.

Aberle AG (2009) Thin-film solar cells. Thin Solid Films 517(17):4706-4710. https://doi.org/10.1016/j.tsf.2009.03.056

Barbosa R, Escobar B, Sanchez VM, Hernandez J, Acosta R, Verde Y (2014) Sizing of a solar/hydrogen system for high altitude long endurance aircraft. International Journal of Hydrogen Energy 39(29):16637-16645. https://doi.org/10.1016/j.ijhydene.2014.05.152

Becker C, Sontheimer T, Steffens S, Scerf S, Bern R (2011) Polycrystalline silicon thin films by high-rate electron- beam evaporation for photovoltaic applications - influence of substrate texture and temperature. Energy Procedia 10:61-65. https://doi.org/10.1016/j. egypro.2011.10.153

Bhatnagar P, Nema RK (2013) Maximum power point tracking control techniques : State-of-the-art in photovoltaic applications. Renewable and Sustainable Energy Reviews 23:224-241. https://doi.org/10.1016/j.rser.2013.02.011

Bialasiewicz JT (2008) Renewable energy systems with photovoltaic power generators: operation and modeling. IEEE Transactions on Industrial Electronics 55(7):2752-2758. https://doi.org/10.1109/TIE.2008.920583 
Bicer Y, Dincer I (2017) Life cycle evaluation of hydrogen and other potential fuels for aircraft. International Journal of Hydrogen Energy 2(42):10722-10738. https://doi.org/10.1016/j.ijhydene.2016.12.119

Böer KW (2011) Cadmium sulfide enhances solar cell efficiency. Energy Conversion and Management 52(1):426-430. https://doi. org/10.1016/j.enconman.2010.07.017

Bossert RH, Tool CJJ, Roosmalen JAM, Wentink CHM, De Vaan MJM (2000) Thin film solar cells: technology evaluation and perspectives. (DV 1.1.170). ECN Report.

Boucher RJ (1985) Sunrise, the world's first solar-powered airplane. Journal of Aircraft 22(10):840-846. https://doi. org/10.2514/3.45213

Bouselham L, Hajji M, Hajji B, Bouali H (2017) A new MPPT-based ANN for photovoltaic system under partial shading conditions. Energy Procedia 111:924-933. https://doi.org/10.1016/j.egypro.2017.03.255

Braun PV, Cho J, Pikul JH, King WP, Zhang H (2012) High power rechargeable batteries. Current Opinion in Solid State \& Materials Science 16(4):186-198. https://doi.org/10.1016/j.cossms.2012.05.00르

Britt J, Ferekides C (1993) Thin-film CdS/CdTe solar cell with 15.8\% efficiency. Applied Physics Letters 62:2851. https://doi. org/10.1063/1.109629

Cairns EJ, Albertus P (2010) Batteries for electric and hybrid-electric vehicles. Annual Review of Chemical and Biomolecular Engineering 1:299-320. https://doi.org/10.1146/annurev-chembioeng-073009-100942

Cestino E (2006) Design of solar high altitude long endurance aircraft for multi-payload \& operations. Aerospace Science and Technology 10(6):541-550. https://doi.org/10.1016/j.ast.2006.06.001

Chen W, Bernal LP (2008) Design and performance of low Reynolds number airfoils for solar-powered flight. Presented at: 46th AlAA Aerospace Sciences Meeting and Exhibit; Reno, USA. https://doi.org/10.2514/6.2008-316

Cleave V (2008) Solar power: a flight to remember. Nature 451(7181):884-886. https://doi.org/10.1038/451884a

Colozza A (2004) Feasibility of a long duration solar powered aircraft on Venus. Presented at: 2nd International Energy Conversion Engineering Conference; Providence, USA. https://doi.org/10.2514/6.2004-5558

Danjuma SB, Omar Z, Abdullah MN (2018) Review of Photovoltaic Cells for Solar-Powered Aircraft Applications (2018) International Journal of Engineering \& Technology 7:131-135.

Davey P (2009) Zephyr HALE UAS. High Altitude Long Endurance Unmanned Aerial System. Presented at: European Command and African Command Science \& Technology Conference; Stuttgart, Germany.

Dimova-Malinovska D (2010) The state-of-the-art and future development of the photovoltaic technologies - the route from crystalline to nanostructured and new emerging materials. Journal of Physic: Conference Series 253(1):012007. https://doi.org/10.1088/1742$6596 / 253 / 1 / 012007$

Emery K (2004) Photovoltaic efficiency measurements. Proc. SPIE 5520, Organic Photovoltaics 3:36-44. https://doi. org/10.1117/12.562712

Esram T, Chapman PL (2007) Comparison of photovoltaic array maximum power point tracking techniques. IEEE Transactions on Energy Conversion 22(2):439-449. https://doi.org/10.1109/TEC.2006.874230

Essig S, Ward S, Steiner MA, Friedman DJ, Geisz JF, Stradins P, Young DL (2015) Progress towards a 30\% efficient GalnP/Si tandem solar cell. Energy Procedia 77:464-469. https://doi.org/10.1016/j.egypro.2015.07.066

Fazelpour F, Vafaeipour M, Rahbari O, Shirmohammadi R (2013) Considerable parameters of using PV cells for solar-powered aircraft. Renewable and Sustainable Energy Reviews 22:81-91. https://doi.org/10.1016/j.rser.2013.01.016

Femia N, Granozia D, Petrone G, Spagnuolo G, Vitelli M (2006) Optimized One-Cycle Control in Photovoltaic Grid-Connected Applications. IEEE Transactions on Aerospace and Electronic Systems 42(3):954-972. https: //doi.org/10.1109/TAES.2006.248205

Fraas LM (2014) Low-cost solar electric power. New York: Springer.

Frulla G, Cestino E (2008) Design, manufacturing and testing of a HALE-UAV structural demonstrator. Composite Structures 83(2):143153. https://doi.org/10.1016/j.compstruct.2007.04.008

Fujita K, Nagai H, Asai K (2012) Conceptual design of a miniature, propeller-driven airplane for Mars. Presented at: 50th AIAA Aerospace Sciences Meeting; Nashville, USA. https://doi.org/10.2514/6.2012-847

Gao X, Hou Z, Guo Z, Chen X (2015) Reviews of methods to extract and store energy for solar-powered aircraft. Renewable and Sustainable Energy Reviews 44(109):96-108. https://doi.org/10.1016/j.rser.2014.11.025

Ghosh K, Guha A, Duttagupta SP (2017) Power generation on a solar photovoltaic array integrated with lighter-than-air platform at low altitudes. Energy Conversion and Management 154:286-298. https://doi.org/10.1016/j.enconman.2017.10.039 
Goetzberger A, Hebling C, Hans-werner S (2003) Photovoltaic materials, history, status and outlook. Material Science and Engineering 40(1):1-46. https://doi.org/10.1016/S0927-796x[02]00092-X

Gómez-Candón D, López-Granados F, Caballero-Novella JJ, Gómez-Casero M, Jurado-Expósito M, García-Torres L (2011) Geo-referencing remote images for precision agriculture using artificial terrestrial targets. Precision Agriculture 12(6):876-891. https://doi.org/10.1007/ s11119-011-9228-3

Gong M, Shastry TA, Xie Y, Bernardi M, Jasion D, Luck KA, Marks TJ, Grossman JC, Ren S, Hersam MC (2014) Polychiral semiconducting carbon nanotube-fullerene solar cells. Nano Letters 14(9):5308-5314. https://doi.org/10.1021/nl5027452

Goodenough JB (2012) Rechargeable batteries: challenges old and new. Journal of Solid State Electrochemistry 16(6):2019-2029. https://doi.org/10.1007/s10008-012-1751-2

Goodenough JB, Park K-S (2013) The Li-Ion rechargeable battery: a perspective. Journal of America Chemical Society 4(135):1167-1197. https://doi.org/10.1021/ja3091438

Han G, Zhang S, Boix PP, Helena L, Sun L (2017) Progress in materials science towards high efficiency thin film solar cells. Progress in Materials Science 87:246-291. https://doi.org/10.1016/j.pmatsci.2017.02.003

Hartney CJ (2012) Conceptual design of a model solar-powered unmanned aerial vehicle. Presented at: 50th AIAA Aerospace Sciences Meeting; Nashville, USA. https://doi.org/10.2514/6.2012-134

Hasegawa K, Ohnmishi M, Takeshima K, Matsumaru Y, Tamura K (1994) Nickel—metal hydride batteries. International Journal of Research in Physical Chemistry and Chemical Physics 183:325-331. https://doi.org/10.1524/zpch.1994.183.Part_1_2.325

Hegedus S, Desai D, Thompson C (2007) Voltage dependent photocurrent collection in CdTe/CdS solar cells. Progress in Photovoltaic 15(7):587-602. https://doi.org/10.1002/pip.767

Hegedus S, McCandless BE (2005) CdTe contacts for CdTe/CdS solar cells: effect of Cu thickness, surface preparation and recontacting on device performance and stability. Solar Energy Material and Solar Cell 88:75-95. https://doi.org/10.1016/j.solmat.2004.10.010

Hillhouse HW, Beard MC (2009) Current opinion in colloid \& interface science solar cells from colloidal nanocrystals : fundamentals, materials, devices, and economics. Current Opinion in Colloid \& Interface Science 14(4):245-259. https://doi.org/10.1016/j.cocis.2009.05.002

Hutchinson H [2016] Solar impulse closes the circle. Mechanical Engineering Magazine; ASME. https://www.asme.org/topics-resources/ content/solar-impulse-closes-the-circle

lles PA (2001) Evolution of space solar cells. Solar Energy Material and Solar Cell 68(1):1-13. https://doi.org/10.1016/S0927$0248(00) 00341-X$

Itoh M, Takahashi H, Fujii T, Takakura H, Hamakawa Y, Matsumoto Y (2001) Evaluation of electric energy performance by democratic module PV system field test. Solar Energy Material and Solar Cell 67(1-4):435-440. https://doi.org/10.1016/S0927-0248(00)00312-3

Jeon BH, Yeon JH, Kim KM, Chung IJ (2002) Preparation and electrochemical properties of lithium-sulfur polymer batteries 109(1):89-97. https: / /doi.org/10.1016/S0378-7753(02)00050-2

Kazmerski LL (2006) Solar photovoltaics R \& D at the tipping point : a 2005 technology overview. Journal of Electron Spectroscopy and Related Phenomena 150:105-135. https://doi.org/10.1016/j.elspec.2005.09.004

Khan J, Arsalan MH (2016) Solar power technologies for sustainable electricity generation - a review. Renewable and Sustainable Energy Reviews 55:414-425. https://doi.org/10.1016/j.rser.2015.10.135

Khurana A, Nayak A, Pacholi A, Shah R (2014) Design and Fabrications of Solar Powered Unmanned Aerial Vehicle. Pilani: IIT Bombay and Birla Institute of Technology and Science.

Klöckner A, Schlabe D, Looye G (2012) Integrated simulation models for high-altitude solar-powered aircraft. Presented at: AIAA Modelling and Simulation Technologies Conference; Minneapolis, USA. https://doi.org/10.2514/6.2012-4717

Kobayashi K, Takano I, Sawada Y (2003) A study on a two-stage maximum power point tracking control of a photovoltaic system under partially shaded insolation conditions. Presented at: IEEE Power Engineering Society General Meeting; Toronto, Canada. https://doi. org/10.1109/PES.2003.1271058

Latukhina N, Rogozin A, Puzyrnaya G, Lizunkova D, Gurtov A (2015) Efficient silicon solar cells for space and ground-based aircraft. Procedia Engineering 104:157-161. https://doi.org/10.1016/j.proeng.2015.04.107

Lee J, Kim ST, Cao R, Choi N, Liu M, Lee KT (2011) Metal-air batteries with high energy density : Li-Air versus Zn-Air. Advanced Energy Materials 1(1):34-50. https://doi.org/10.1002/aenm.201000010

Leutenegger S, Jabas M, Siegwart RY (2011) Solar airplane conceptual design and performance estimation : what size to choose and what endurance to expect. Journal of Intelligent and Robotic Systems: Theory and Applications 61:545-561. https://doi.org/10.1007/ s10846-010-9484-x 
MacCready PB, Lissaman PBS, Morgan WR, Burke JD (1983) Sun-powered aircraft designs. Journal of Aircraft 20(6):487-493. https: // doi.org/10.2514/3.44898

McCann MJ, Catchpole KR, Klaus JW, Blakers AW (2001) A review of thin-crystalline silicon for solar cell applications. Part 1: native substrates. Solar Energy Materials and Solar Cells 68(2):135-171. https://doi.org/10.1016/S0927-0248(00)00242-7

Mecrow BC, Bennett JW, Jack AG, Atkinson DJ, Freeman AJ (2010) Drive topologies for solar-powered aircraft. IEEE Transactions on Industrial Electronics 57(1):457-464. https://doi.org/10.1109/TIE.2009.2031190

Meier J, Flückiger R, Keppner H, Shah A (1994) Complete microcrystalline p-i-n solar cell-Crystalline or amorphous cell behavior? Applied Physics Letters 65:860. https://doi.org/10.1063/1.112183

Meier JU, Kroll EV-S, Spitznagel J, Graf U, Shah A (2004) Amorphous solar cells, the micromorph concept and the role of VHF-GD deposition technique. Solar Energy 77:983-993. https://doi.org/10.1016/j.solener.2004.08.026

Meyer EL, Dyk EE (2003) Characterization of degradation in thin-film photovoltaic module performance parameters. Renewable Energy 28:1455-1469. https://doi.org/10.1016/S0960-1481(02)00062-9

Michael G (2003) Dye-sensitized solar cells. Jounal of Photochemistry and Photobiology 4:145-153. https://doi.org/10.1016/S13895567(03)00026-1

Morton S, D’Sa R, Papanikolopoulos N (2015) Solar powered UAV: design and experiments. Presented at: IEEE International Conference on Intelligent Robots and Systems; Hamburg, Germany. https://doi.org/10.1109/IROS.2015.7353711

Najafi Y (2011) Design of a high altitude long endurance solar powered UAV (Master's Thesis). San Jose: San Jose State University.

Nazeeruddin MK, Baranoff E, Michael G (2011) Dye-sensitized solar cells: a brief overview. Solar Energy 85:1172-1178. https://doi. org/10.1016/j.solener.2011.01.018

Noth A (2008) Design of solar powered airplanes for continuous flight (PhD Dissertation). Zumholz: ETH Zurich.

Noth, A., Bouabdallah, S., Michaud, S., Siegwart, R., \& Engel, W. (2004). Sky-sailor design of an autonomous solar powered Martian airplane. Presented at: 8th ESA Workshop on Advanced Space Technologies for Robotic and Automation; Noordwijk, The Neitherlands. https: / /doi.org/10.3929/ethz-a-010085369

Noth A, Engel W, Siegwart R (2006) Recent progresses on the Martian solar airplane project skysailor. Presented at: 9th ESA Workshop on Advanced Space Technologies for Robotics and Automation; Noordwijk, The Netherlands. https://doi.org/10.3929/ethz-a-010079386

Nozik AJ (2002) Quantum dot solar cells. Physica E: Low-dimensional Systems and Nanostructures 14(1-2):115-120. https://doi. org/10.1016/S1386-9477(02)00374-0

Padbury R, Zhang X (2011) Lithium-oxygen batteries — Limiting factors that affect performance. Journal of Power Source 196(10):44364444. https://doi.org/10.1016/j.jpowsour.2011.01.032

Pande D, Verstraete D (2018) Impact of solar cell characteristics and operating conditions on the sizing of a solar powered nonrigid airship. Aerospace Science and Techonology 72:353-363. https://doi.org/10.1016/j.ast.2017.11.013

Park M, Yu I (2004) A study on the optimal voltage for MPPT obtained by surface temperature of solar cell. Presented at: 30th Annual Conference of IEEE Industrial Electronics Society; Busa, South Korea. https://doi.org/10.1109/IECON.2004.1432110

Peumans P, Yakimov A, Forrest SR (2003) Small molecular weight organic thin-film photodetectors and solar cells. Journal of Applied Physics 93:3693. https://doi.org/10.1063/1.1534621

Radue C, Dyk EE, Macabebe EQ (2009) Analysis of performance and device parameters of CIGS PV modules deployed outdoors. Thin Solid Films 517(7):2383-2385. https://doi.org/10.1016/j.tsf.2008.11.011

Rajendran P, Smith $\mathrm{H}$ (2015) Implications of longitude and latitude on the size of solar-powered UAV. Energy Conversion and Management 98:107-114. https://doi.org/10.1016/j.enconman.2015.03.110

Ram JP, Babu TS, Rajasekar N (2017) A comprehensive review on solar PV maximum power point tracking techniques. Renewable and Sustainable Energy Reviews 67:826-847. https://doi.org/10.1016/j.rser.2016.09.076

Ramírez-díaz G, Nadal-Mora V, Piechocki J (2015) Descriptive analysis of viability of fuel saving in commercial aircraft through the application of photovoltaic cells. Renewable and Sustainable Energy Reviews 51:138-152. https://doi.org/10.1016/j.rser.2015.06.008

Reddy SBK, Aneesh P (2017) Performance analysis of solar powered Unmanned Aerial Vehicle. Renewable Energy 104:20-29. https:// doi.org/10.1016/j.renene.2016.12.008

Repins I, Contreras MA, Egaas B, DeHart C, Scharf J, Perkins CL, To B, Noufi R (2008) 19.9\%-efficient ZnO/CdS/ CulnGaSe 2 solar cell with 81.2\% fill factor. Progress in Photovoltaics 16(3):235-239. https://doi.org/10.1002/pip.822

Ross H (2008) Fly around the world with a solar powered airplane. Presented at: 26th Congress of ICAS and 8th AIAA ATIO; Anchorage, USA. https://doi.org/10.2514/6.2008-8954 
Rydh CJ, Karlström M (2002) Life cycle inventory of recycling portable nickel-cadmium batteries. Resources, Conservation and Recycling 34(4):289-309. https://doi.org/10.1016/S0921-3449(01)00114-8

Sahnoun MA, Ugalde HMR, Carmona JC, Gomand J (2013) Maximum power point tracking using P\&O control optimized by a neural network approach: A good compromise between accuracy and complexity. Energy Procedia 42:650-659. https://doi.org/10.1016/j. egypro.2013.11.067

Salas V, Olías E, Barrado A, Lázaro A (2006) Review of the maximum power point tracking algorithms for stand-alone photovoltaic systems. Solar Energy Materials and Solar Cells 90(11):1555-1578. https://doi.org/10.1016/j.solmat.2005.10.023

Satyen KD (1998) Recent developments in high efficiency photovoltaic cells. Renewable Energy 15(1-4):467-472. https://doi. org/10.1016/S0960-1481(98)00206-7

Scrosati B, Garche J (2010) Lithium batteries : status, prospects and future. Journal of Power Sources 195(9):2419-2430. https: //doi. org/10.1016/j.jpowsour.2009.11.048

Shiau JK, Ma DM, Yang PY, Wang GF, Gong JH (2009) Design of a Solar Power Management System for an Experimental UAV. IEEE Transactions on Aerospace and Electronic Systems 45(4):1350-1361. https://doi.org/10.1109/TAES.2009.5310303

Sliwinski J, Gardi A, Marino M, Sabatini R (2017) Hybrid-electric propulsion integration in unmanned aircraft. Energy 140:1404-1416. https://doi.org/10.1016/j.energy.2017.05.183

Stacy NJS, Craig DW, Staromlynska J, Smith RB (2002) The global hawk UAV Australian deployment: imaging radar sensor modifications and employment for maritime surveillance. Presented at: IEEE International Geoscience and Remote Sensing Symposium; Toronto, Canada. https://doi.org/10.1109/IGARSS.2002.1025623

Tan P, Kong W, Shao Z, Liu M, Meng N (2017) Advances in modeling and simulation of Li À air batteries. Progress in Energy and Combustion Science 62:155-189. https://doi.org/10.1016/j.pecs.2017.06.001

Tanaka M, Taguchi M, Matsuyama T, Sawada T, Tsuda S, Nakano S, Hanafusa H, Kuwano Y (1992) Development of new a-Si/c-Si heterojunction solar cells: ACJ-HIT (artificially constructed junction-heterojunction with intrinsic thin-layer). Japanese Journal of Applied Physics 31(11):3518. https://doi.org/10.1143/JJAP.31.3518

Tsang KM, Chan WL (2013) Energy Conversion and Man agement Model based rapid maximum power point tracking for photovoltaic systems. Energy Conversion and Management 70:83-89. https://doi.org/10.1016/j.enconman.2013.02.018

Tudron FB, Akridge JR, Puglisi VJ (2004) Lithium-sulfur rechargeable batteries : characteristics, state of development, and applicability to powering portable electronics. Power sources 1-4.

Tyagi W, Rahim NAA, Rahim NA, Selvaraj JAL (2013) Progress in solar PV technology: research and achievement. Renewable and Sustainable Energy Reviews 20:443-461. https://doi.org/10.1016/j.rser.2012.09.028

Wagner FT, Lakshmanan B, Mathias MF (2010) Electrochemistry and the future of the automobile. Journal of Physical Chemistry Letters 1(14):2204-2219. https://doi.org/10.1021/jz100553m

Wagner L (2007) Overview of Energy Storage Methods. Mora Associates Research Report.

Wang NC, Wu MY, Shi GS (2011) Study on characteristics of photovoltaic cells based on MATLAB simulation. Presented at: Asia-Pacific Power Energy Engineering Conference; Wuhan, China. https://doi.org/10.1109/APPEEC.2011.5748713

Zhang L, Lv M, Meng J, Du H (2017) Optimization of solar-powered hybrid airship conceptual design. Aerospace Science and Technology 65:54-61. https://doi.org/10.1016/j.ast.2017.02.016

Zhang SS (2013) Liquid electrolyte lithium/sulfur battery: Fundamental chemistry, problems, ad solutions. Journal of Power Sources 231:153-162. https://doi.org/10.1016/j.jpowsour.2012.12.102 